医学図書館 $21(3 \cdot 4): 219 \sim 233,1974$

\title{
医学総説論文の書誌類 Bibliographies of Medical Reviews
}

\section{は じめに}

最近，〈総説〉或は〈Review〉といら言葉を耳にする ことが多い。しかし，それらについて書かれた論文は医 学の分野に関していえば比較的少い。そしてそれらの論 文も主に総説或は Review (以下 Review に統一) の重 要性の面に力点を拉いて論じている場合が多い。そこ で,ここではこの特集の趣旨に幾らかでも添うょうに, また図書館の参考業務担当者にとって直接役立つよう 飞，実務的な面からこのテーマを扱ってみようと思う。

すなわち Review はいかなる方法で探したらよいか， またある特定主題に関してどのような Review 誌があ るか，といら方法である。ただ，Review を扱うに当っ てはやはり Review とは一体どういうものなのか，とい う点からはじめなければならないと思う。そこで全体を 3 章に分け，第 1 章では Review についての簡単な概説 を述べ，第 2 章では Review を探すための代表的な $2 つ$ の tool の解説を, 第 3 章には Review 誌の主題別リス トを付した。な就論文中で扱った資料は全て欧文とし， 日本語による資料については今回は問題点を指摘するこ とと，参考文献をあげる程度にとどめた。これは日本に 扔いては Review についての扱いがまだ十分に確立して いないことによるものである。

\section{Review についての概論}

(1) Review の定義

Review の定義については幾つかなされているが，そ れぞれの間に基本的に大きな差異はない。ここでは高橋

* University of Tokyo Medical Library: Research Group on Medical Reviews

\section{東京大学医学図書館* \\ 青木公男・藤森末雄 \\ 青木弘行. 早川英子}

達郎ほか「科学文献〈まとめ方・さがし方・利用の仕方〉」 （南江堂，昭和 41）により次のように教えておきたい。 すなわち『ある特定の問題について，いままで発表され た重要な研究開発上の成果を総合的に展望して, それに ついての批判や論評を加え, 現在までの進歩の状態や動 向を明らかに示すようにまとめて発表したもの。』

(2) Review の形態

上記の定義によりこんぞは Review が資料中にどのよ うな形で存在するか分析してみよう。そうすると Review は意外にもかなり多種類の形で見いだすことがで きる。たとえば我々が通常雑誌とよんでいる一次資料の 中に Review 記事を継続して揭載している形がある。揭 載している雑誌がある，というよりはむしろ掲載してい る雑誌が多いといったほうが正確であろう。また Review という名称を誌名に冠して発行される雑誌もある。 更には Review のみをまとめて図書形態で逐次的に刊行 される場合もある。このように Review の在り方は多様 であるが，ここでは Review を形態面から分類して図式 化してみよう。（図1）

このらち Review を探す tool とついては第 2 章で代 表的な 2 誌について具体的に説明するので省略するが， Review のみをまとめて揭載したものについて若干説明 を加えて抗こう。これらは通常我々が Review 誌とよん でいる資料で㐫り，外観的には図書形態を有し，ある一 定の主題分野についての主要な研究論文を, 期間を限り, 網羅的に収集し，展望し，また評価を加えたもので,特定 分野の現状や将来のあり方を知る上には大変に利用価值 の高いものといえる。特に編集者にその分野の権威者が 当る場合が多く，それだけに内容が高度に維持されて括 り, 今後, 利用者にとっての文献調査活動にはこれら

医学図畫館 21 巻 $3 \cdot 4$ 号 ('74) 
図 1 : Reviews の形態的分類

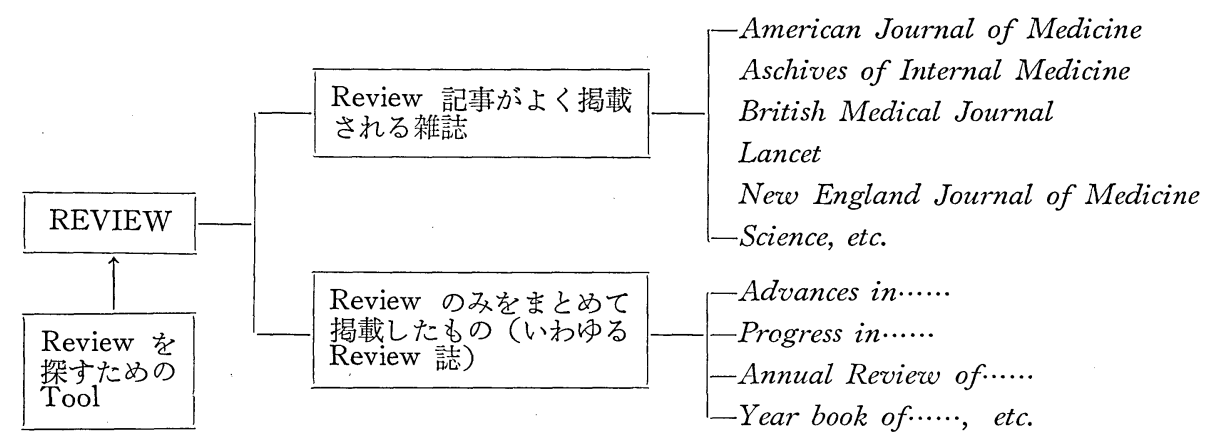

1. Bibliography of Medical Reviews (1956- )

2. Index to Scientific Revierws (1974- )

3. Annual Review of Pharmacology, Review of Reviews (1961- )

4. Biological Abstracts, BASIC (1963- )

5. Chemical Abstracts, 抄録番号の前に “ $\mathrm{R} ”$ を付したもの

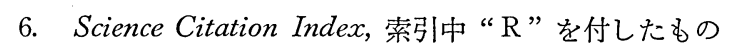

7. 出版社のカタログ等

Review 誌の活用が大きな比重を占めてくるものと思わ れる。その意味からも第 3 章に Review 誌の主題別リス 卜を作成した。な扰通常我々は Review 誌を二次資料と して扱っているが(この点に関しては若干の異論もあり, Review 誌を一次資料として扱っている場合もある)，そ のような扱い方をした場合には Review がよく揭載され る雑誌は一次資料, Review を探す tool は三次資料と よぶこともできよう。

（3）現代における Review の意義

現代は情報の時代といわれる。確かに電子計算機をは じめとして, 各種の情報機器の発達はぼう大な量の情報 を生み出している。ある一人の研究者が，それらの大量 の情報の中から自分の研究にとって本当に有用な文献を 見つけ出すことは次第に困難な状況になってきている。 そのよらな時代において Review 誌の持つ意義とはどう いらことであろらか。以下考劣られる点を二，三あげて みよう。まず最初に，ある特定の研究分野についての現 状を概観したい場合がある。このような時に原著論文を ひとつづつ読むことは時間の無䭾であろらし, 或は目的 とする論文を見いだすことさえ困難であるう。そのよう な場合 Review は効果的である。特に Review 誌は主 題別, 年代別に調査できる利点があり, 短時間のうちに 目的を達成できよう。次に学問領域の学際化の問題があ る。科学技術の進歩は新しい学問分野を創り出すと同時 に各学問分野間の境界をあいまいにし複雑化した。この
ことは研究者にとって, 自己の研究分野の情報のみに頼 っていては新しい発展は望めないことを意味する。研究 者は少なくとも関連領域の情報にまで注意を払わねばな らない。このような場合 Review による方法はやはり有 効的であろう。また昨今の資料購入費の高騰は雑誌の購 入を著しく困難にした。索引誌, 抄録誌等に収載されて いる一次資料を全て所蔵することは一図書館としては不 可能なことである。このことは索引，或は抄録誌等によ る検索の意味を少なからずうすいものにしてしまった。 このことも Review 誌のもつ現代的な意味を增している ように思われる。

\section{(4) 今後の問題}

以上述べてきたところからも明らかなように, Review は今後益々その必要性, 有効性を高めてゆくものと思わ れる。と同時に今後に残された問題も幾つか考兄られ る。最後にその点について問題点をあげてみよう。まず 最初に日本語の Review の問題がある。この問題につい ては最初に簡単にふれた通りまだ有効的な使用の状態に あるとはいい難い。Review 誌の数も少い。医学分野で はわずかに「現代医学シリーズ」（あすへの内科展望, あすへの外科展望, あすへの整形外科展望, あすへの産 婦人科展望, あすへの小児科展望, あすへの眼科展望, あすへの皮膚科展望，1972/72一，金原出版）がようや くその第一歩をふみ出したという感じである。外国文献 に頼らざるを得ない日本の医療の状態の中で, 日本語の 
Review が発展してゆく道はけわしいが，今ひとつの充 実が望まれる。

そして更に我々図書館員の問題としてひとつ取上げる ならば，Review に対する図書館側の関心の低さの問題 がある。Index Medicus, Excerpta Medica 等の二次资 料に比べて関心がうすいといらことは，資料とのものが 一次資料に近いといら形態的な面等それなりの問題はあ るとしても，現代が Review を必要としているという背 景を考光た場合, その要求に応えることはやはり园書館 の役割のひとつであろう。

\section{Review を探すための Tool}

\section{(1) Bibliography of Medical Reviews}

1956 年に NLM から発行された定期刊行物内の Review 記事を案内するための索引誌である。最初はCurrent List of Medical Literature の副産物として作られ たもので, 内容はその前年の Current List の中の Review 記事を抜萃したもので年刊形式の独立出版物であ った。本文は件名毎に Review 記事を列挙したもので試 験的に出されたものであったが，好評を受けて定期刊行 物として定着することになった。1960 年からは Index Medicus 収録源が変化したが，出版形式は年刊で続け られ, 1967 年に新たな利用層の拡大を目ざして Monthly Index Medicus の重要な一部分を構成するようになっ た。遡及的検索には 5 年間の累積版も発行されており便 利である。現在は医学及び関連領域の専門家が，その主 題についての最新の Review を求める場合に最も包括的 な参考 tool となっている。

〈収録基準〉

この Bibliography を編集する際に雑誌内のぞういっ た論文を Review として採用するのかが編集者の間で問 題になっていた。その選択基準がはっきりと確立してい なかったために，多分にその選択内容が主観性を帯びて しまい,その戦密な基準確立の必要性が認識されてきた。 その結果 1964 年にその基準が作られ，その後一応の統 一性を見るに至っている。従ってその後の収録数にかな りの量的減少をもたらした。以下にこの Bibliography の選択基準の大略を述べる。

(1) Annual review series, Advances in series, Nutrition review 等, いわゆる一般に Review 誌と して認められている出版物内の記事や, Uebersicht, Rassegna, Revue, Annuell 等の章の中含まれている 記事, New England Journal of Medicine の様な雑誌
内に Review といら言葉を論題に持っている記事は収録 される。

（2）論題の中に Review and case report という言 葉が含まれる記事は，その内容が基準を満たしている純 然たる Review である場合に限り収録される。統計に関 する Review むその分野で権威的なものについては收録 される。

（3）次に収録されない記事について述べると，事例 報告やある主題についての歴史を扱ったもの，内容の大 半が参考文献であるもの, 雑誌に揭載された論文主題の 単なる要約にすぎないもの, 卒業論文, 学位論文が Review であるもの，ある主題に導入するだあ付けられ た長い序文が Review であるもの等である。

また Scandinavian, Acta series の Supplement は 個人研究の導入的意味を有している入門的 Review に相 当するため収録されない。主題の多局面を扱うものや臨 林医のための入門課程に当る内容のものも省かれる。以 上の様に多分に Critical review の包括的書誌としての 性格を強く打ち出したものということができよう。

〈構成〉

索引化や体裁については Montyly Index Medicus や Cumulated Index Medicus とまったく同じである。収 録源も 1965 年からは Index Medicus に限定されてい る。内容は Subject Section (図 2) と Author Section （図 3）の二部から構成されて扮り，Subject の項目は当 然 MeSH を採用している。Monthly が年刊に Cumulate されて Cumulated Index Medicus の Author Section の前につけられている。以下に各巻の構成と収録件数を 参考岕げて扔く(表 1 )。

\section{(2) Index to Scientific Reviews}

従来の索引に执いて Review がどのように扱われてき たかについて見てみると，1956 年からは先にとりあげた Bibliography of Medical Reviews が出ており, 生物学 分野では Biological Abstracts の BASIC (Keywordin-Context Subject Index) がありまたChemical Abstracts, Science Citation Index (以下 $S C I$ と略す) では “R”マークを付してReview であることを示している。

Review の探索といら点から見た場合, Bibliography of Medical Revierus 以外性, 時間的にも元の成果に打い ても効率のよいものではないといえる。それは Review 数が 全文献数に占める割合（約 3 4 \%) が少ないこと や，SCI 以外の従来の索引には特定の主題件名標目表が 介在していることなどが考光られるが，Review がこれ 
表 1 : Bibliography of Medical Reviews 各巻の構成と収録件数

\begin{tabular}{|c|c|c|c|}
\hline 巻 数 & 刊年 & 構 成 & 収録 件 数 \\
\hline 1 & 1956 & Subject & 1,075 \\
\hline 2 & 1957 & Subject & 2,000 \\
\hline 3 & 1958 & Subject, Author & 2,885 (585: non-CL) \\
\hline 4 & 1959 & Subject, Author & 3,241 (434: non-CL) \\
\hline 5 & 1960 & Subject, Author & 2,382 \\
\hline $1 \sim 6$ (Cumulation) & 1961 & Subject & v. $6: 3,300$ \\
\hline 7 & 1962 & Subject & \\
\hline 8 & 1963 & Subject & $6,633(1,214:$ non-IM) \\
\hline 9 & 1964 & Subject & 3,266 (207: non-IM) \\
\hline 10 & 1965 & Subject, Name & 4,510 (240: non-IM) \\
\hline 11 & 1966 & Subject, Name & 4, 071 (17: non-IM) \\
\hline 12 & 1967 & Subject, Name & 4,590 \\
\hline
\end{tabular}

以後 Index Medicus に収録

図 2 : Bibliography of Medical Reviews-Subject Section

other primates. Passingham RE, et al. Int Rev Neuroblol 16(0):233-99, 197 (269 ref.)

\section{CERebrosides}

[Brain cerebrosides] Promyslov MSh, et al.

Yopr Med Khlm 18(3):227-40, 1972 (173 ref.) (Eng
Abstf.)

\section{CERVIX NEOPLASMS}

Radiotherapy of carclnoma of the cervix. Brizel HE, Fiveash AE, Howington JW. J Mod Amsoc Ga 63(9):357.61, Sep 74 (17 ref.)

\section{CHALONES}

Candidate hormones of the gut. XVII. Antral chalone. Thompson JC. Gastroenterology 67(4):752-4, Oct 74 (25 ref.)

\section{CHARCOAL}

Management of acute poisoning with activated charcoal. Corby DG, et al. Podintrics 5s(3):324-9, Sep 74 ( 31 ref.)

\section{CHICKENS}

Some effects of high environmental temperatures on the productivity of laying hens (a review). Smith AJ. Trop Aaim Health Prod 5(4):258-71, Nov 73 (56 ref.)

\section{CHILD BEHAVIOR}

Behavior modiflcation: new tools for use in pediatric dentistry with the handicapped chlld. Drash PW. Dent Clu North Am 18(3):617-31, Jul 74 (11 ref.)

\section{CHILD BEHAVIOR DISORDERS}

Behavior modification: new tools for use in podlatric dentistry with the handlcapped chlld. Drash PW. Deat Clin North Am 18(3):617-s1, Jul 74 (11 ref.)
12(9):521-8, Sep 74 ( 81 ref.)

\section{CHROMATOGRAPHY, GAS}

Utilization of gas-liquid chromatography coupled with chemical lonization and electron impact mass spectrometry for the investigation of potentialiy hazardous environmental agents and thelr metabolltes. Oswald EO, et al. J Chromatogr 98(2):363-448, 25 Sep 74 (313 ref.)

\section{CHROMATOGRAPHY, ION EXCHANGE}

RNA Practionation on hydroxyapatite columns. Kotharl RM, et al. \& Chromatogr 08(2):449-75, 25 Sop 74 (140 ref.)

\section{CIRCADIAN RHYTHM}

Dally rhythms of sterold and associated pitultary hormones in man and their relationship to sleep. Daly JR, et al. Adv Sterold Blochem Pharmacol 4(0):61-110, 1974 (248 ret.)

\section{COENZYME A}

Relationships between coenzyme $Q$ and vitamin $\mathbf{E}$. Folkers K. Am J Clin Natr 27(8):1026-34, Sep 74 (21 ref.)

\section{COGNITION DISORDERS}

[Problems in the diagnosls of mild early infantile brain damage in chlldren] Machemer $P$.

Prax Kinderpaychol Kinderpeychlater 23(4):125-9, May-Jun 74 ( 34 ref.)

(Ger)

\section{COLITIS, ULCERATIVE}

[Ulcerative-necrotic disease of the intestine In premature and newborn infants (literature survey)] Alekseevskikh IuG, et al. Vopr Okhr Materin Det 19(7):59-63, 1974 (78 ref.) 
図 3 : Bibliography of Medical Reviews-Author Section

\section{$\mathbf{K}$}

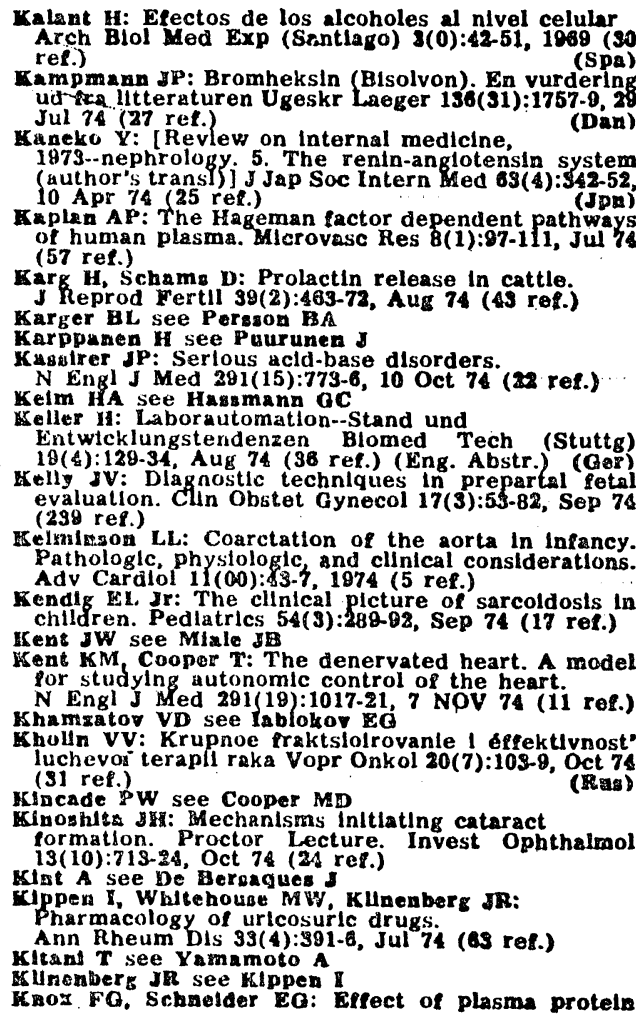

らの索引の本来的対象ではないためである。

Index to Scientific Reviews (以下 ISR 々略す) はこ らした難点を補う Review 専門の索引として 1974 年よ り登場した。対象が 自然科学全般であり医学は約 $40 \%$ 強を占めるに過ぎないが，Review 探索の有効な手段と なり得るものである。ISR は半年毎の soft-bound と, 2 巻からなる hard-bound の年間累積版とからなり,その 収録範囲は世界の主要科学雑誌や Review 誌の約 2,400 誌で，年間 16,000 以上の Review がカバーされる。

\section{〈收載基準〉}

$I S R$ を出版しているのが $S C I$ を出版している ISI 社であることからも分かるように, ISR と $S C I$ とは同 一のデータベースを用いている。すなわち，SCI の磁気 テープから，最初にタイトル中に“Advances in…...”, “Progress in......", “Critical review of......", と言っ た語句を持つものを選び，次に 40 以上の reference を xuttig H: Strahlentheraple der Tumoren des
Zentralnervensystems im KIndesalter
Strahlentheraple 147(4):335-43, Apr 74 (22 ref.)
(Eng. Abstr.)

\section{$\mathbf{L}$}

Lanke $\mathbf{K}$ see Stormorken $\mathrm{H}$

Labovits J see Mullex $W$

Lecy PE: Structure and function of the endocrine cell types of the Islets. Adv Metab Disord $7(0): 171-82$. 1974 (14 ref.).

Lalho KA see Trump BF

Lambert AE see Remold AE

Lambjerg-Hansen $\mathrm{H}$ : Vital and mortal pulpectomy on permanent human teeth. An experimental comparative histologic investlgation. Scand $J$ Dent Res $82(4): 243-334,1972$ (202 ref.) Lamon IW: The Immune response to virally Blochim Blophys Acta \$55(2):149-76, 9 Sep 74 (177 ref.)

Lampe KF: Systemic plant polsoning In chlldren. Pedlatrics 54(3):347-51, Sep 74 (8 ref.)

Lance EM see Porter 13

Landmark KF: Atrloventrikulaerknutens fyslologl og farmakologl Tidsskr Nor Laegeforen

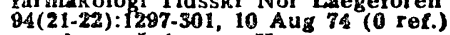

(Nor)

Lang A see Lehrami

ager GA: Calclum in mammalian myocardium. Localization, control, and the effects of digitalis.

Circ Res 35(3):91-8, Sep 74 (32 ref.)

Langer $T$ see Loyy

Linube II see Pfelifer icr

Lavanar $8 P$ see plrart

havary see Prart anatomle van de long bij de prematuur geboren baby en bij de zogenaamde "hyallene membraanzlekte Verh K Vlaam Acad Geneeskd Belg $34(3): 239339$, Verh K Vlaam Acad Geneeskd Belg 34(3):239339,
1972 (141 ref.)

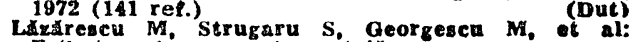
Pslhoterapla comportamental Neurol Psihlatr Neurochir 18(3):183-201, May-Jun 74 (23 ref.)
(Rum)

Lefebvre $P$. Layckx A: Glucagon et substrats énergetlques Journ Annu Dlabetol Hotel Dleu energetlques Journ Annu Dlabetol Hotel Dleu
(Fro):03-107 1972 (62 ref.) ceffert RD: Brachial-plexus infuries. $N$ Engl J Mod $291(20): 1059-67,14$ Nov 74 (57 re?.)

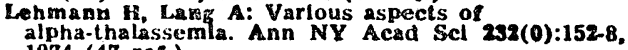

Lehninger AL: Cast transport by witcchondrla and

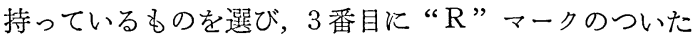
ものを選び出し，更にこれらを専門家が精選している。

ISR の特長は, 第一に引用索引であることである。引用 索引は，研究者の文献探索が引用文献から引用文献へと 行なわれることに着目してこれを索引に応用している。 第二に, 主題索引に特定の件名標目表が無く,タイトル中 の主要語を並べ替えたものであることである。また $I S R$ を利用の面から見た場合には，自分の研究或いは自分と 同じ研究領域の他の人の研究がどのように評価され，ま た以後どのように展開されたかを容易に知り得ること，

新しく研究を開始しようとする時に，その分野の研究の 現状を効率的に知り得ることなどがあげられる。

〈構成〉

$I S R$ の構成は SCI とほとんど同一であり, Citation Index, Source Index, Permuterm Subject Index, Patent Citation Index, Corporate Index から成っている。 
図 4 : Index to Scientific Reviews-Citation Index

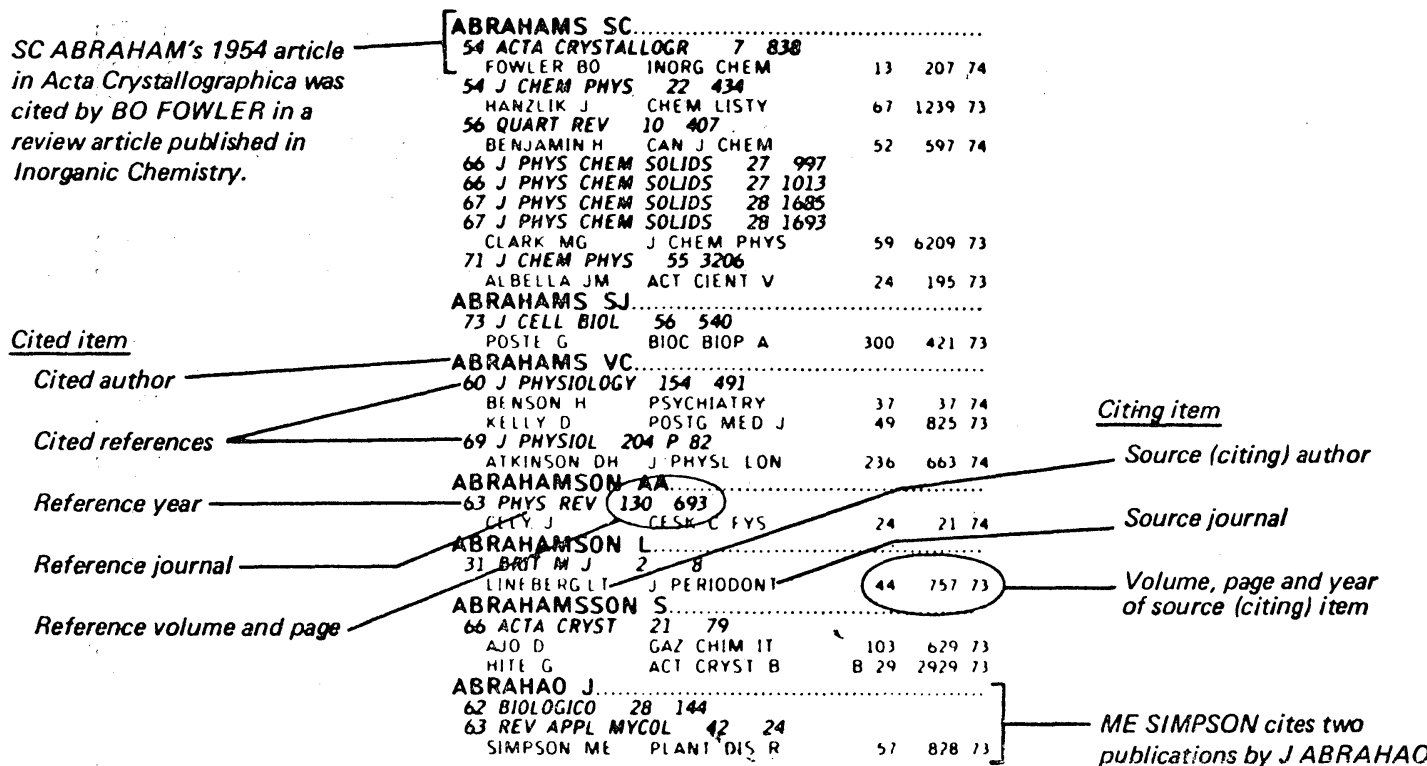

図 5 : Index to Scientific Reviews-Source Index

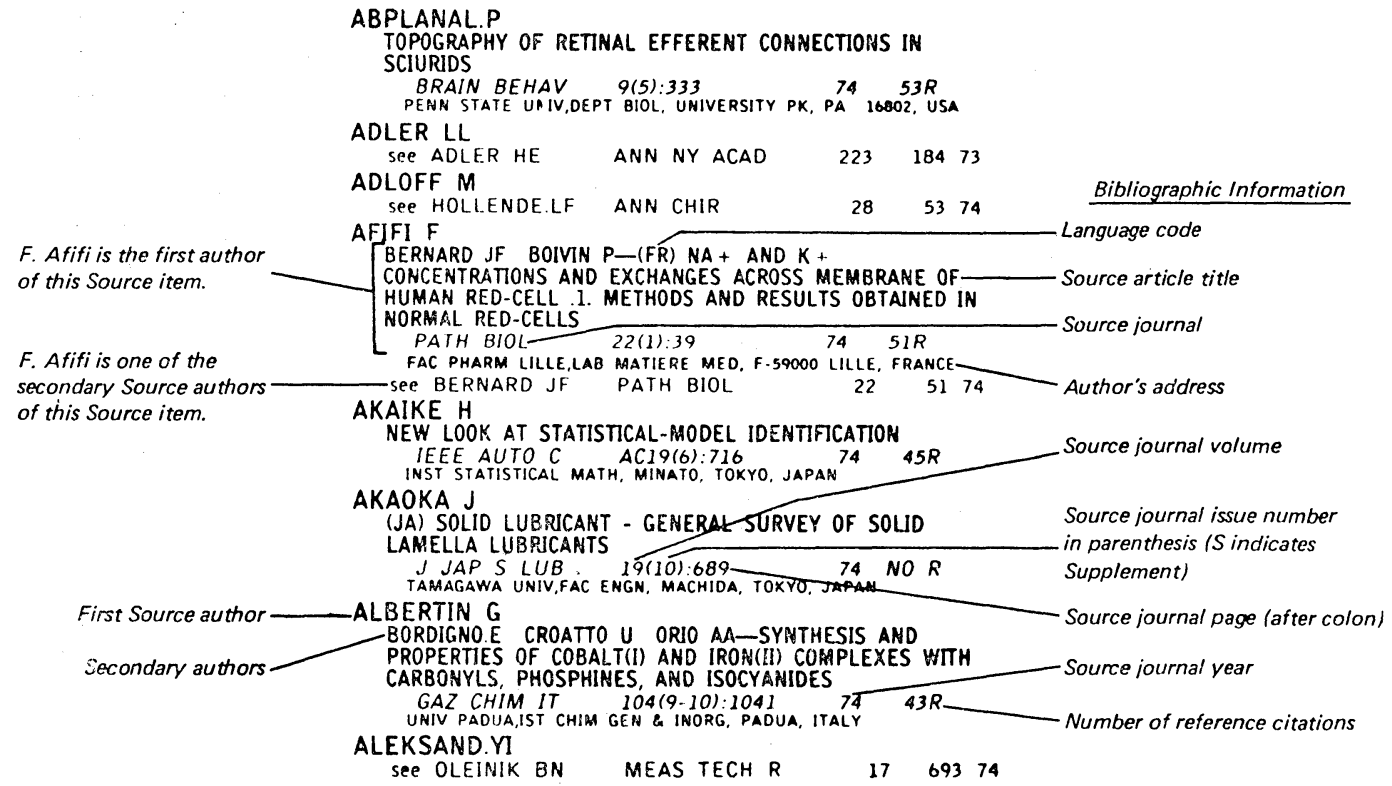

Citation Index (図 4)

単行畫, 百科事典, 或いは従来の索引類で既知の著者 名から，その著者の論文が以後誰によって，ぞのような 雑誌に引用されたかがわかり，これ等の引用文献の中か ら求める研究主題に 関連のある 文献を探すことができ
る。またこの作業を繰り返すことによって多くの文献を 得ることが可能となる。

Source Index (図 5)

Citation Index で求められた著者名から， Source Index でその著者の Review 記事に関する完全な書誌 
図 6 : Index to Scientific Reviews-Permuterm Subject Index

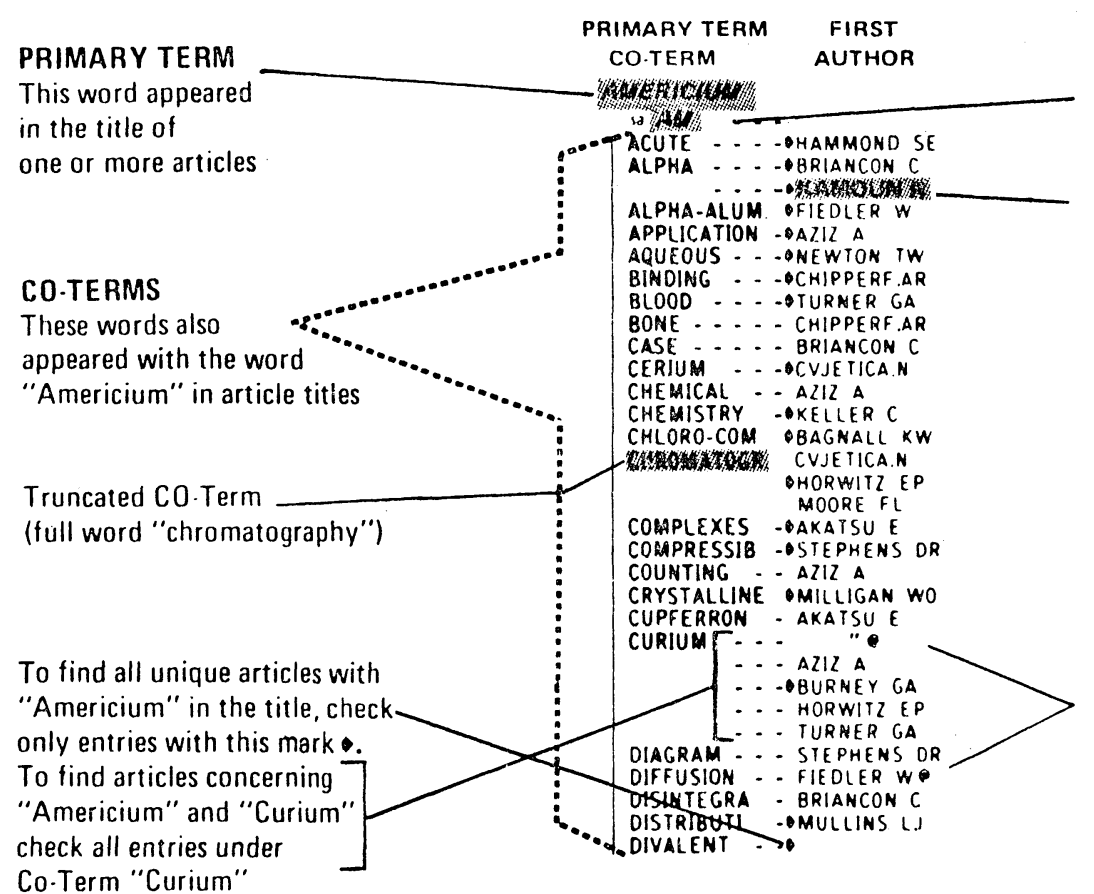

Cross Reference

("sa" means "see also")

Co.Term Identical

to Co.Term."Alpha" above

The "@” sign indicates that each of these authors has written more than one article with the relevant primary and co-terms in their titles. Consult the Source Index.

図 7 : Index to Scientific Reviews-Patent Citation Index

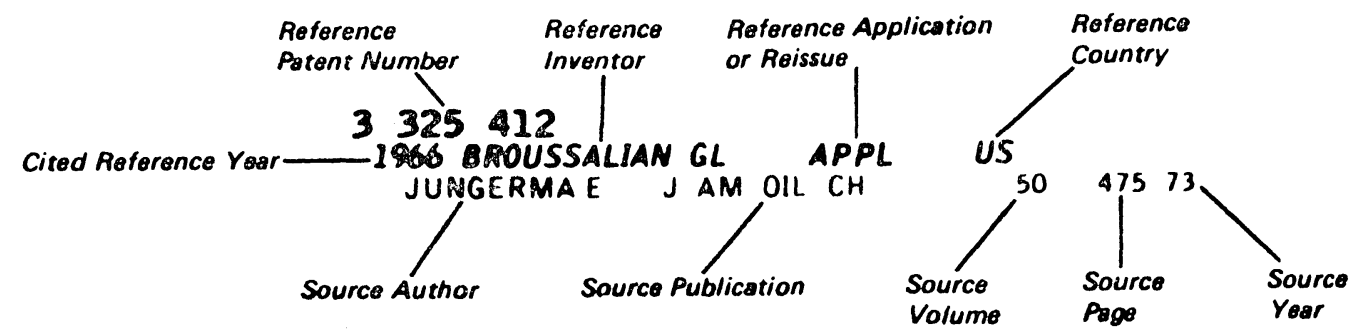

的事項を得ることができる。

Permuterm Subject Index (図 6)

Source Index に載っているすべての Review 記事の タイトル, サブタイトルから主要な語, 語句を抜き出し, アルファベット順に並び替え，主記入（primary term） と副記入（co-term）の組合わせを作ることによって， より限定された主題の 探索を可能にしている。従来の subject index が特定の件名標目の下に文献が配列され ているのに対し，これは自然言語, 最新の用語によって 迅速に探索できる利点を持っている。

\section{Patent Citation Index (図 7)}

この Index は Review 記事に引用されたり，参照さ れた特許を特許番号順に配列したもので，ある既知の特
許が Review 記事においてどのように論じられている かを知りたい時に使われる。

Corporate Index

研究機関名をアルファベティカルに配列したもので， 求める主題領域に打沙幾つかの著名な機関名から Review 記事を探索することができる。

\section{おわりに}

現代における医学がより広い，より新鮮な，より深い 知識を要求しているならば, 編者の経験とエネルギーの 集中された Review は現代の最も理想的な資料といって も過言ではあるまい。しかし先にもふれたように，Review はまだ十分に利用されているとはいい難い。第 3 
章で我々は Review 誌の主題別リスト化を試みたが，こ のリストが何らかのかたちで Review の利用に役立つも のであれば幸いと思う。しかしこのリストを作成するに 当っても幾つかの問題点は残った。ここにリスト作成上 の選定プロセスと問題点を記して今後の課題としたい。 まずReview 誌の選定は「現行医学䧴誌所在目録 1975 年版」に記載されているタイトルを基礎データとし，そ の中から 346 誌を選出した。選出に当っては東大医学図 書館で所蔵している Review 誌, 他館で所蔵していて Review 誌と確認できる資料にもとづいた。分類主題見 出乙語は, Excerpta Medica の Section titles, MeSH 1975 年版, List of Journals indexed in Index Medicus の Subject Listing を参考にして作成した。分類分析に ついては東大所蔵の資料はともかくとして，直接資料を 確認できなかった他館所蔵の資料, 特に基礎科学分野の 資料の分析には多少不確定の 部分も含まれるかもしれ ない。そのためタイトルによっては分類重出を行うこと によってカバーした。また 346 誌に限定したことは，網 羅性といら点からいえば問題は残るかもしれない。この リストに含まれていない資料を所蔵して打られる館もい くつかあることと思う。Review と分類分析に対して, ひろく御意見をいただきたいと思う。

\section{Review 誌の主題別リスト}

\section{ALLERGY see IMMUNOLOGY}

\section{ANATOMY, ANTHROPOLOGY, EMBRYOLOGY and HISTOLOGY}

Advances in Anatomy, Embryology and Cell Biology. Berlin

Advances in Cell Biology. Amsterdam Advances in Morphogenesis. New York Advances in Teratology. New York Advances in Tissue Culture. Baltimore Annual Review of Anthropology. Palo Alto Current Topics in Cellular Regulation. New York Current Topics in Developmental Biology. New York

International Review of Connective Tissue Research. New York

International Review of Cytology. New York Methods in Cell Biology. New York Monographs in Clinical Cytology. Basel Monographs in Developmental Biology. Basel
Progress in Histochemistry and Cytochemistry. Stuttgart

ANTHROPOLOGY see ANATOMY, ANTHROPOLOGY, EMBRYOLOGY and HISTOLOGY ANESTHESIOLOGY

Appraisal of Current Concepts in Anesthesiology. St. Louis

Modern Trends in Anaesthesia. London Monographs in Anaesthesiology. Amsterdam

Year Book of Anesthesia. Chicago

BACTERIOLOGY SE MICROBIOLOGY : BACTERIOLOGY, MYCOLOGY and PARASITOLOGY BIOCHEMISTRY

Advances in Carbohydrate Chemistry and Biochemistry. New York

Advances in Catalysis. New York

Advances in Cell and Molecular Biology. New York

Advances in Clinical Chemistry. New York

Advances in Comparative Physiology and Biochemistry. New York

Advances in Cyclic Nucleotide Research. New York

Advances in Enzyme Regulation. Oxford Advances in Enzymology and Related Areas of Molecular Biology. New York

Advances in Food Research. New York

Advances in Lipid Research. New York Advances in Metabolic Disorders. New York Advances in Protein Chemistry. New York Advances in Steroid Biochemistry and Pharmacology. New York

Annual Review of Biochemistry. Palo Alto

Current Topics in Membranes and Transport. New York

Essays in Biochemistry. London

Experiments in Physiology and Biochemistry. New York

Methods of Biochemical Analysis. New York Methods in Carbohydrate Chemistry. New York Methods in Enzymology. New York

Methods in Hormone Research. New York

Nutrition Abstracts and Reviews. Aberdeen 
Nutrition Reviews. New York

Progress in Bioorganic Chemistry. New York

Progress is Biophysics and Molecular Biology. New York

Progress in the Chemistry of Fats and Other Lipids. London

Progress in Molecular and Subcellular Biology. Berlin

Progress in Nucleic Acid Research and Molecular Biology. New York

Progress in Separation and Purification. New York Recent Advances in Hormone Research. New York Reviews of Physiology, Biochemistry and Pharmacology. Berlin

Standard Methods in Clinical Chemistry. New York

Topics in Lipid Chemistry. London

Vitamins and Hormones. New York

World Review of Nutrition and Dietetics. London

BIOENGINEERING see BIOPHYSICS, BIOENGINEERING and MEDICAL INSTRUMENTATION

\section{BIOLOGY}

see also BOTANY

see also ZOOLOGY

Advances in Behavioral Biology. New York

Advances in the Biosciences. Oxford

Advances in Cell Biology. Amsterdam

Advances in Cell and Molecular Biology. New York

Advances in Ecological Research. London

Advances in Marine Biology. New York

Annual Review of Ecology and Systematics. Palo Alto

Biological Reviews of the Cambridge Philosophical Society. London

Cold Spring Harbor Symposia on Quantitative Biology. Cold Spring Harbor, N.Y.

Current Topics in Comparative Pathobiology. New York

Current Topics in Developmental Biology. New York

Developments in Biological Standardization. Basel
Frontiers of Biology. Amsterdam

Methods in Cell Biology. New York

Methods in Cell Biology. New York

Methods in Membrane Biology. New York

Monographs in Developmental Biology. Basel

Progress in Molecular and Subcellular Biology. Berlin

Progress in Surface and Membrane Science. New York

Progress in Theoretical Biology. New York

Quarterly Review of Biology. New York

Results and Problems in Cell Differentiation. Berlin

Survey of Biological Progress. New York

Symposia of the International Society for Cell

Biology. New York

BIOPHYSICS, BIOENGINEERING and MEDICAL

INSTRUMENTATION

see also PHYSICS

Advances in Biochemical Engineering. Berlin

Advances in Biological and Medical Physics. New York

Advances in Biomedical Engineering and Medical

Physics. New York

Advances in Molecular Relaxation Processes. Amsterdam

Annual Review of Biophysics and Bioengineering. Palo Alto

Biomedical Science Instrumentation. New York

Current Topics in Bioenergetics. New York

Current Topics in Membranes and Transport. New York

Methods in Membrane Biology. New York

Modern Trends in Biomechanics. London

Progress in Biocybernetics. Amsterdam

Progress in Biophysics and Molecular Biology.

New York

Progress in Surface and Membrane Science. New York

Theoretical and Experimental Biophysics. New York

\section{BOTANY}

Annual Review of Phytopathology. Palo Alto Annual Review of Plant Physiology. Stanford 
Progress in Phytochemistry. London

Recent Advances in Phytochemistry. New York

\section{CANCER}

Avances in Cancer Research. New York

Canadian Cancer Conference. Oxford

Methods in Cancer Research. New York

Monographs on Neoplatic Diseases at Various Sites.

Edinburgh

National Cancer Institute Monographs. Washington

Progress in Clinical Cancer. New York

Progress in Experimental Tumor Research. Basel

Recent Results in Cancer Research. Berlin

Year Book of Cancer. Chicago

\section{CARDIOVASCULAR SYSTEM}

Actualites Cardio-Vascularies Medicochirurgicales. Paris

Advances in Cardiology. Basel

Advances in Cardiopulmonary Diseases. Chicago

Advances in Microcirculation. Basel

Aktuelle Probleme in der Angiologie. Bern

Progress in Hemostasis and Thrombosis. New York

Modern Trends in Cardiac Surgery. London

Modern Trends in Vascular Surgery. London

Verhandlungen der Deutschen Gesellschaft für Kreislaufforschung. Darmstadt

Year Book of Cardiovascular Medicine and Surgery. Chicago

\section{CHEMISTRY}

see also BIOCHEMISTRY

see also PHARMACOLOGY

Advances in Analytical Chemistry and Instrumentation. New York

Advances in Carbohydrate Chemistry and Biochemistry. New York

Advances in Chemistry Series. Washington

Advances in Chromatography. London

Advances in Colloid and Interface Science. Amsterdam

Advances in Fluorine Chemistry. New York

Advances in Heterocyclic Chemistry. New York

Advances in Inorganic Chemistry and Radiochemistry. New York

Advances in Mass Spectrometry. New York
Advances in Organic Chemistry. New York Advances in Organometalic Chemistry. New York Advances in Photochemistry. New York Advances in Physical Organic Chemistry. London Advances in Quantum Chemistry. New York Advances in Spectroscopy. New York

Annual Reports on the Progress of Chemistry. Sec. $A, B$. London

Annual Review of Physical Chemistry. Palo Alto Essays in Chemistry. London

Fortschritte der Chemie Organischer Naturstoffe. Wien

Organic Syntheses. New York

Progress in Bioorganic Chemistry. New York Progress in Infrared Spectroscopy. New York Progress in Inorganic Chemistry. New York Progress in Organic Chemistry. London

Progress in Physical Organic Chemistry. New York Progress in Polarography. New York

Progress in Separation and Purification. New York Progress in Stereochemistry. London

Progoess in Thin-layer Chromatography and Related Methods. Michigan

CHEMOTHERAPY see PHARMACOLOGY CLINICAL CHEMITRY sE BIOCHEMISTRY COMPUTERS

Computing Reviews. New York

\section{CYTOLOGY see ANATOMY, BIOLOGY DENTISTRY}

Advances in Fluorine Research and Dental Caries Prevention. New York

Advances in Pedodontics. Chicago

Current Therapy in Dentistry. St. Louis

Modern Trends in Dental Surgery. London

Year Book of Dentistry. Chicago

\section{DERMATOLOGY and VENEREAL DISEASES}

Advances in Biology of Skin. New York Current Problems in Dermatology. Basel

Fortschritte der Praktischen Dermatologie und Venereologie. Berlin

Modern Trends in Dermatology. London

Year Book of Dermatology. Chicago

DIGESTIVE SYSTEM 
Frontiers of Gastrointestinal Research. Basel

Modern Trends in Gastroenterology. London

Progress in Gastroenterology. New York

Progress in Liver Diseases. New York

EMBRYOLOGY see ANATOMY, ANTHROPO-

LOGY, EMBRYOLOGY and HISTOLOGY

\section{ENDOCRINOLOGY}

Current Topics in Experimental Endocrinology.

New York

Memoirs of the Society for Endocrinology. Cambridge

Methods in Hormone Research. New York

Modern Trends in Endocrinology. London

Recent Progress in Hormone Research. New York

Year Book of Endocrinology. Chicago

ENTMOLOGY see ZOOLOGY

ENVIRONMENTAL HEALTH

see also INDUSTRIAL MEDICINE

Advances in Environmental Sciences and Technology. New York

Modern Trends in Occupational Health. London

Residue Reviews. New York

\section{FORENSIC MEDICINE}

Modern Trends in Forensic Medicine. London

GASTROENTEROLOGY see DIGESTIVE SYSTEM GENERAL MEDICINE

Advances in Experimental Medicine and Biology.

New York

Advances in Internal Medicine. New York

Annual Review of Medicine. Palo Alto

Ciba Foundation Study Group. Amsterdam

Ergebnisse der Inneren Medizin und Kinderheilkunde. Berlin

Fortichritte der Medizin. Munchen

Harvey Lectures. New York

Scientific Basis of Medicine, Annual Reviews.

London

Year Book of Medicine. Chicago

\section{GENTICS}

Advances in Genetics. New York

Advances in Human Genetics. New York

Annual Review of Genetics. Palo Alto

Progress in Medical Genetics. New York

\section{GERONTOLOGY and GERIATRICS}

Advances in Gerontological Research. New York GYECOLOGY see OBSTETRICS and GYNECOLOGY

HEART see CARDIOVASCULAR SYSTEM

\section{HEMATOLOGY}

Actualites Hematologiques. Paris

Advances in Blood Grouping. New York

Clinics in Haematology. London

Fortschritte der Haematologie. Leipzig

Hematologic Review. New York

Progress in Hematology. New York

HEREDITY see GENETICS

HISTOLOGY see ANATOMY, ANTHROPOLOGY, EMBRYOLOGY and HISTOLOGY

HYGIENE see ENVIRONMENTAL HEALTH

IMMUNOLOGY, SEROLOGY and TRANSPLANTATION

Advances in Immunology. New York

Advances in Transplantation. Kobenhavn

Clinical Immunology and Immunopathology. New York

Contemporary Topics in Immunobiology. New York

Current Topics in Microbiology and Immunology. Berlin

Methods in Immunology and Immunochemistry. New York

Modern Trends in Immunology. Washington

Monographs in Allergy. Basel

Progress in Allergy. Basel

Progress in Clinical Immunology. New York

Symposia Series in Immunobiogical Standardization. Basel

\section{INDUSTRIAL MEDICINE}

Modern Trends in Occupational Health. London

INTERNAL MEDICINE see GENERAL MEDICINE LIBRARY SCIENCE

Advances in Information System Science. New York Advances in Librarianship. New York

Annual Review of Information Science and Technology. New York

Progress in Library Science. London

LIVER see DIGESTIVE SYSTEM 


\section{MEDICAL INSTRUMENTATION see BIOPHYSICS METABOLISM}

Advances in Metabolic Disorders. New York MICROBIOLOGY : BACTERIOLOGY, MYCOLOGY and PARASITOLOGY

Advances in Applied Microbiology. New York Advances in Microbial Physiology. New York Advances in Parasitology. London Annual Review of Microbiology. Stanford Bacteriological Reviews. Baltimore

Current Topics in Microbiology and Immunology. Berlin

Methods in Microbiology. London

Progress in Industrial Microbiology. London

MYCOLOGY see MICROBIOLOGY : BACTERIO-

LOGY, MYCOLOGY and PARASITOLOGY

NEPHROLOGY see UROLLGY

\section{NEUROLOGY and NEUROSURGERY}

Actualites Neurophysiologique. Paris

Advances in Chemoreception. New York

Advances in Neurology. New York

Advances in Neurosurgery. Berlin Advances in Sleep Research. New York Advances in Stereoencephalotomy. Basel

Clinical Neurosurgery. Baltimore

Fortschritte der Kiefer- und Gesichts-Chirurgie. Stuttgart

Fortschritte der Neurologie, Psychiatrie und ihrer Grenzgebiete. Stuttgart

International Review of Neurobiology. New York Methods of Neurochemistry. New York

Modern Trends in Neurology. London Monographs on Neural Science. Basel

Progress in Brain Research. New York

Progress in Hemostasis and Thrombosis. New York

Progress in Neurobiology. Oxford

Progress in Neurological Surgery. Basel

Progress in Neurology and Psychiatry. New York Progress in Neuropathology. New York

Research and Clinical Studies in Headache; an International Review. Basel

Year Book of Neurology and Neurosurgery. Chicago
NUCLEAR MEDICINE see RADIOLOGY and NUCLEAR MEDICINE

\section{OBSTETRICS and GYNECOLOGY}

Advances in Obstetrics and Gynecology. Baltimore

Fortschritte der Geburtshilfe und Gynaekologie. Basel

Modern Trends in Gynecology. London

Modern Trends in Obstetrics. London

Progress in Gynecology. New York

Year Book of Obstetrics and Gynecology. Chicago OPHTHALMOLOGY

Advances in Ophthalmology. Basel

Current Concepts in Ophthalmology. St. Louis

Documenta Ophthalmologica. Den Haag

Modern Problems in Ophthalmology. Basel

Modern Trends in Ophthalmology. London

Year Book of Ophthalmology. Chicago

ORTHOPEDIC SURGERY

Current Practice in Orthopedic Surgery. St. Louis Ergebnisse der Chirurgie und Orthopädie. Berlin Modern Trends in Orthopaedics. London

Year Book of Orthopedics and Traumatic Surgery. Chicago

\section{OTORHINOLARYNGOLOGY}

Advances in Oto-Rhino-Laryngology. Basel

Year Book of the Ear, Nose and Throat. Chicago

PARASITOLOGY see MICROBIOLOGY : BACTERIOLOGY, MYCOLOGY and PARASITOLOGY PATHOLOGY

Archiv und Atlas der Normalen und Pathologischen Anatomie in Typischen Roentgenbildern. Stuttgart

Current Topics in Pathology. Berlin

International Review of Experimental Pathology. New York

Methods and Achivements in Experimental Patho$\log y$. Basel

Modern Trends in Pathology. London

Progress in Clinical Pathology. New York

Year Book of Pathology and Clinical Pathology. Chicago

\section{PEDIARICS}

Advances in Child Development and Behavior. 
New York

Advances in Pediatrics. New York

Modern Problems in Pediatrics. Basel

Modern Trends in Paediatrics. London

Progress in Pediatric Radiology. Basel

Progress in Pediatric Surgery. Munchen

Year Book of Pediatrics. Chicago

\section{PHARMACOLOGY and PHARMACY}

Actualites Pharmacologiques. Paris

Advances in Biochemical Psychopharmacology.

New York

Advances in Chemotherapy. New York

Advances of Clinical Pharmacology. Munchen

Advances in Colloid and Interface Science. Amsterdam

Advances in Cytopharmacology. New York

Advances in Drug. Research. London

Advances in Pharmaceutical Sciences. London

Advances in Pharmacology and Chemotherapy. New York

Advances in Steroid Biochemistry and Pharmacology. New York

Annual Review of Pharmacology. Palo Alto

Antibiotics and Chemotherapy. Basel

Drug Metabolism Reviews. New York

Essays in Toxicology. New York

Medicinal Chemistry; a Series of Monographs.

New York

Methods in Pharmacology. New York

Modern Problems in Pharmacopsychiatry. Basel

Modern Trends in Pharmacology and Therapeutics.

London

Modern Trends in Toxicology. London

Progress in Biochemical Pharmacology. Basel

Progress in Chemical Toxicology. New York

Progress in Drug Research. Basel

Progress in Medicinal Chemistry. London

Progress in Toxicology. New York

Residue Reviews. New York

Reviews of Physiology, Biochemistry and Pharmacology. Berlin

Topics in Medicinal Chemistry. New York

Year Book of Drug Therapy. Chicago

\section{PHYSICS}

Advances in Atomic and Molecular Physics. New York

Advances in Chemical Physics. New York

Advances in Optical and Electron Microscopy.

New York

Progress in Reaction Kinetics. Oxford

\section{PHYSIOLOGY}

Actualites Neurophysiologique. Paris

Advances in Metabolic Disorders. New York

Advances in Reproductive Physiology. London

Annual Review of Physiology. Palo Alto

Contributions to Sensory Physiology. New York

Current Topics in Cellular Regulation. New York

Experiments in Physiology and Biochemistry. New

York

Harvey Lectures. New York

Modern Trends in Physiological Medicine. London

Reviews of Physiology, Biochemistry and Pharmacology. Berlin

POLLUTION CONTROL sE ENVIRONMENTAL

\section{HEALTH}

\section{PSYCHIATRY}

Advances in Behavior Therapy. New York

Advances in Psychosomatic Medicine. Nem York

Current Psychiatric Therapies. New York

Fortschritte der Neurologie, Psychiatrie und ihrer Grenzgebiete. Stuttgart

International Review of Research in Mental Retardation. New York

Modern Trends in Mental Health and Subnormality. London

Progress in Learning Disabilities. New York

Progress in Neurology and Psychiatry. New York

Recent Advances in Biological Psychiatry. New York

Year Book of Psychiatry and Applied Mental Health. Chicago

\section{PSYCHOLOGY}

Advances in Experimental Social Psychology. New York

Advances in Study of Behavior. New York

Annual Review of Psychology. Stanford 
Current Topics in Clinical and Community Psycho$\log y$. New York

Methods in Physiological Psychology. New York Progress in Clinical Psychology. New York

Progress in Experimental Personality Research. New York

Progress in Physiological Psychology. New York

\section{RADIOLOGY and NUCLEAR MEDICINE}

Advances in Radiation Biology. New York Advances in Tracer Methodology. New York Advances in X-Ray Analysis. New York Annual Review of Nuclear Science. Stanford Current Topics in Radiation Research Quarterly. Amsterdam

Ergebnisse der Medizischen Radiologie. Stuttgart

Fortschritte auf dem Gebiete der Roentgenstrahlen und der Nuklearmedizin. Stuttgart

Frontiers of Radiation Therapy and Oncology. Basel

Modern Trends in Diagnostic Radiology. London Modern Trends in Radiotherapy. London Progress in Atomic Medicine. New York Progress in Nuclear Energy. New York Progress in Nuclear Medicine. Basel Progress in Pediatric Radiology. Basel Progress in Radiation Therapy. New York Year Book of Nuclear Medicine. Chicago

Year Book of Radiology. Chicago

RESPIRATORY SYSTEM and THORACIC DISEASES

Advances in Tuberculosis Research. Basel

Ergebnisse der Gesamten Lungen und Tuberkuloseforschung. Stuttgart

Progress in Respiration Research. Basel

\section{RHEUMATISM}

Modern Trends in Rheumatology. London

\section{SEROLOGY SE IMMUNOLOGY, SEROLOGY and TRANSPLANTAION \\ SURGERY}

see also NEUROLOGY and NEUROSURGERY Advances in Surgery. Chicago

Aktuelle Probleme in der Chirurgie. Bern

Current Topics in Surgical Research. New York
Fortschritte der Kiefer- und Gesichts-Chirurgie. Stuttgart

Modern Trends in Accident Surgery and Medicine. London

Modern Trends in Plastic Surgery. London Modern Trends in Surgery. Washington Progress in Clinical Surgery. London Progress in Surgery. Basel

Recent Advances in Surgery. London

Surgery Annual. New York

Surgical Forum. Chicago

Wiederherstellungschirurgie und Traumatologie. Basel

Year Book of General Surgery. Chicago

Year Book of Plastic and Reconstructive Surgery. Chicago

THORACIC DISEASES see RESPIRATORY SYSTEM and THORACIC DISEASES

TOXICOLOGY sE PHARMACOLOGY

TRANSPLANTATION see IMMUNOLOGY, SEROLOGY and TRANSPLANTATION

\section{TROPICAL MEDICINE}

International Review of Tropical Medicine. New York

TUBERCULOSIS sE RESPIRATORY SYSTEM and THORACIC DISEASES

\section{UROLOGY and NEPHROLOGY}

Advances in Nephrology from the Nechker Hospital. Chicago

Modern Trends in Urology. London

Year Book of Urology. Chicago

VASCULAR DISEASES see CARDIOVASCULAR SYSTEM

VENEREAL DISEASES see DERMATOLOGY and VENEREAL DISEASES

\section{VETERINARY MEDICINE}

Advances in Veterinary Science and Comparative Medicine. New York

\section{VIROLOGY}

Advances in Virus Research. New York International Virology. Basel Methods in Virology. New York Modern Trends in Medical Virology. London 
Monographs in Virology. Basel

Progress in Medical Virology. Basel

\section{ZOOLOGY}

Advances in Insect Physiology. London

Advances in Primatology. New York

Advances in Small Animal Practice. Oxford

Annual Review of Entomology. Palo Alto

International Review of General and Experimental

Zoology. New York

\section{参考文 献}

1）笹川 統: Review の探し方. 「薬学図畫館」18

(3) : 108 119, 1973

2）関口昌樹 : Review journal の意義と重要性，「薬学
図書館」 15 (2) : 52 59，1970.

3）花田岳美：基礎化学に和けるレビュ一雑誌の展望.

「情報管理」 14 （8）：481～484， 1971.

4）金尾素健 : 三次資料. 「薬学図書館」16（3）：93～ 99, 1971.

5）小谷正雄 : Review of review を作ろう.「学燈」59 (11) : 4 7, 1962.

6）岩本速雄，藤川俊三 : Review 誌その取扱い.「第 8 回医学図書館員研究集会論文集」p. 181 189, 1974.

7) Blake, John B. and Roos, C., ed.: Medical reference works 1957-1966; a selected bibliography. Chicago, MLA, 1967.

（炤和 50 年 11 月 4 日受付）

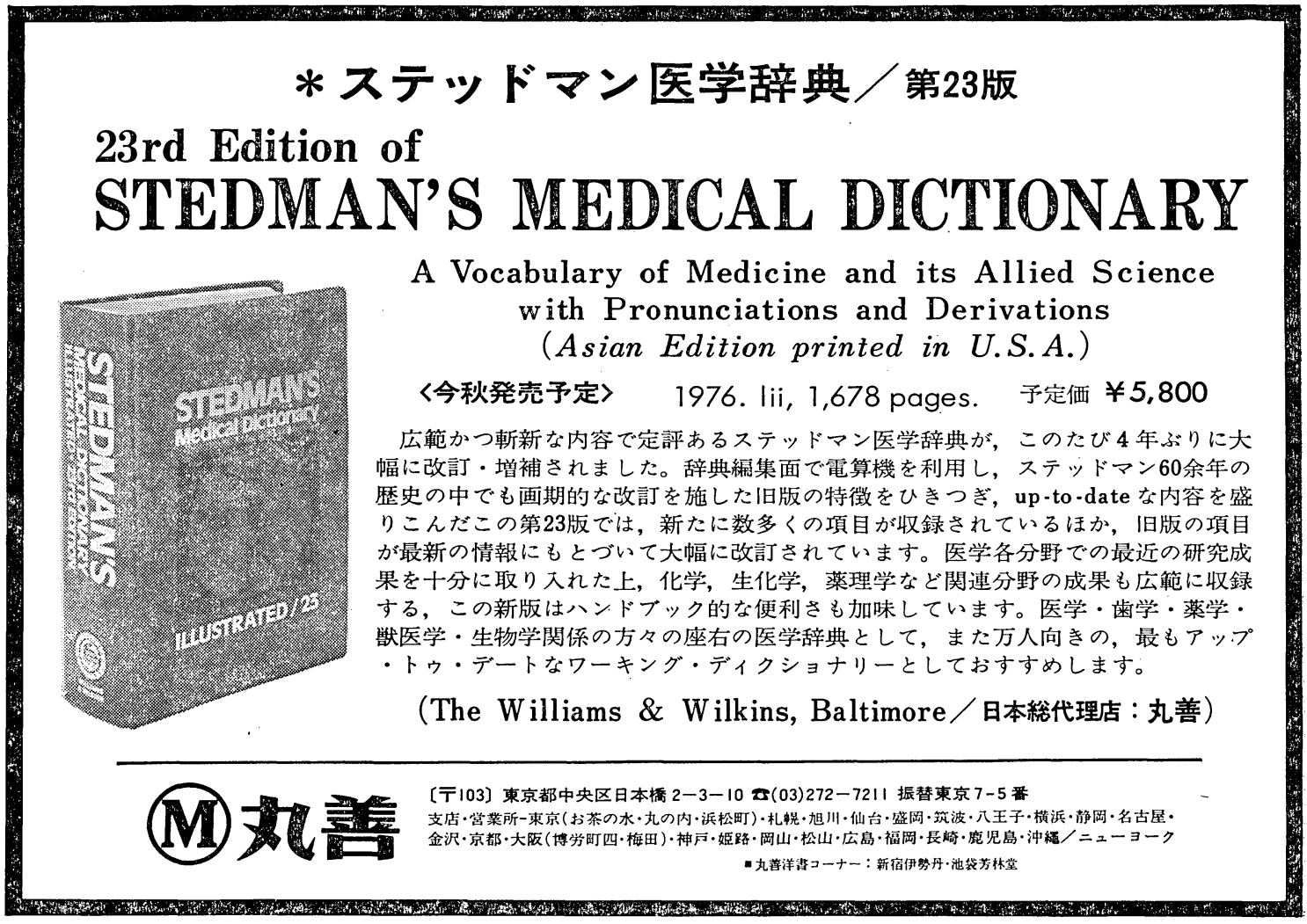

